\title{
COOLING SIMULATION OF CONFORMAL COOLING INJECTION MOULD INSERT PRODUCED BY HYBRID MANUFACTURING
}

\author{
David Homar, Luka Čerče, Janez, Kopač
}

Original scientific paper Cooling of injection moulds manufactured by machining has limitations because cooling channels are formed by conventional straight holes. With additive manufacturing, the cooling channels can be produced in the shape which is adjusted to the cavity and core surface of injection moulds. Those kinds of cooling channels are called the conformal cooling channels. Conformal cooling channels can significantly reduce cycle time of plastic injection moulding process and significantly improve the quality of products. Thus, in this work conformal cooling channels for industrial case study were constructed and analysed. Besides expected tests, cooling simulation has been performed, comparing conventional and proposed cooling technology. Results have been confirmed also by testing prototype with conformal cooling channels, showing significant improvement in reducing cycle time, more than $40 \%$.

Keywords: additive manufacturing; conformal cooling; cooling simulation; hybrid manufacturing

\section{Simulacija hlađenja hibridno izrađenog alata za injekcijsko prešanje polimera s prilagođenim rashladnim kanalima}

Izvorni znanstveni članak Hlađenje alata za injekcijsko prešanje polimera izrađenog obradom odvajanjem čestica ima ograničenja, jer su kanali za hlađenje sastavljeni od uobičajenih ravnih rupa. Aditivnom tehnologijom mogu se izraditi rashladni kanali koji su prilagođeni kalupnoj šupljini. Ta vrsta rashladnih kanala naziva se konformni rashladni kanali. Konformni rashladni kanali mogu znatno smanjiti vrijeme ciklusa proizvodnje pri injekcijskom prešanju i znatno poboljšati kvalitetu proizvoda. U ovom istraživanju su dizajnirani i analizirani konformni rashladni kanali kao zamjena za konvencionalne kanale u alatu za injekcijsko prešanje. Pored uobičajenih ispitivanja izvršena je simulacija hlađenja, uspoređujući konvencionalnu i predloženu tehnologiju hlađenja. Rezultati su potvrđeni i testiranjem prototipa s konformnim rashladnim kanalima, pokazujući značajno poboljšanje u smanjenju vremena, više od 40 \%.

Ključne riječi: aditivna proizvodnja; hibrdna proizvodnja; konformno hlađenje; simulacija hlađenja

\section{Introduction}

In injection moulding, production of tube shoulders is using injection mould tool insert with convectional cooling channels. Tube shoulders are presented in Fig. 1 and tool insert for production of tube shoulders is presented in Fig. 2. These cooling channels are machined. Due to limitations of machining processes, the cooling channels have to be straight. Alternatively, additive manufacturing processes enable manufacturing of inner channels with complex geometry. Thus, proposed is the usage of combination of conventional machining and additive manufacturing technology.

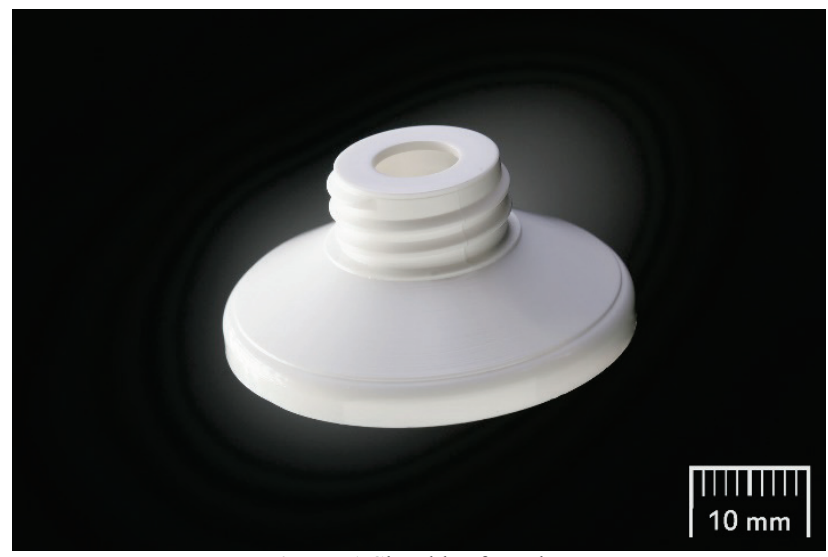

Figure 1 Shoulder for tubes

In the past, some researchers tried to combine technologies for additive manufacturing and machining technologies, but their main purpose was found in making near-net shape and then use milling process to produce finished shape [1]. Other scientists divided CAD model of products into two or more modules, where some modules were produced by milling and others by additive process, subsequently assembled in end product [2], [3] and [4].

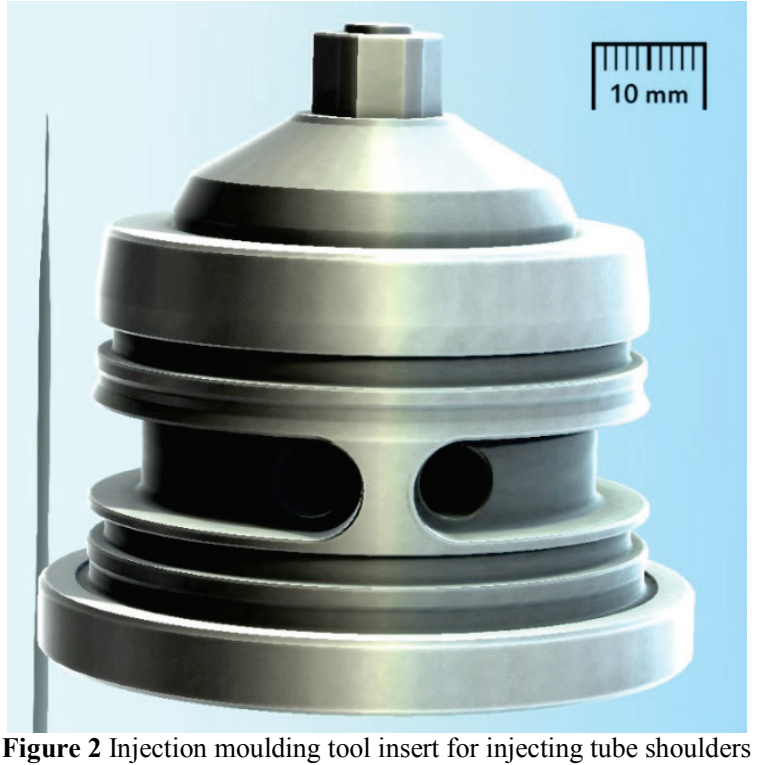

By hybrid manufacturing it is possible to produce parts composed of two or more different metals. This year new paper [5] has been published in which a machine for hybrid manufacturing is introduced along with an application example for oil-energy industry where Inconel 718 features are added on the Stainless Steel alloy (316S31) substrate. It has been found that hybrid manufacturing of that product brings significant reduction in material costs compared to the case where entire part was made of Inconel 718 by machining. 
In our case, milling and turning is combined with selective laser melting technology. Selective laser melting is the process where the layer of metallic powder is melted and fused together layer by layer, with the high powered laser, directly from CAD data to create functional metal parts. Our goal is in order to part of the product which is possible to produce with conventional subtractive process will be manufactured by milling or turning. The other part of product with a complex geometry, which is difficult, impossible or very costly to machine, will be manufactured by selective laser melting (SLM) technology. Therefore the product will be split in two parts, with straight plane, before processing. The base part, in most cases the biggest part, will be manufactured by milling and then the operator will move the intermediate product from milling machine to the machine for selective laser melting. Subsequently, operator will fill building chamber with metal powder and then the machine will start building the second part of product from the upper surface, where the milling machine finished the base part of the product. That kind of production is primarily intended for manufacturing injection moulding tool inserts with conformal cooling system. The conformal cooling system is a term for cooling channels which conform to the contours of the insert or cavity of injection moulding tool or tool for die casting. With conformal cooling system better dimensional accuracy of the moulded part is achieved reducing cycle time of injection moulding up to $40 \%$ [6] and [7]. The conformal cooling channels are very desirable for injection moulding industry. But for conformal cooling system is decided by toolmaker only in special cases, due is not possible to do this system with conventional processes and additive manufacturing processes are too expensive for making entire tool. With that kind of hybrid manufacturing, we want to manufacture moulds for injection moulding cheaper with conformal cooling channel, so that it will be accessible for more toolmakers. Because cutting tool cannot access inner surfaces of conformal cooling channels we decided to combine this process with additive process. With additive process it is not a problem to manufacture conformal cooling channels.

\section{Construction of conformal cooling channels}

Current injection moulding tool insert for moulding tube shoulders which is used in production has some limitations. The shape of current cooling channels is very simple because insert is manufactured by machining. Channels are composed of inlet hole, outlet hole and base channel which is separated to two channels with barrier as is shown in Fig. 3. Cooling channels are located only on one side of the tool and it is expected that tempering of insert is uneven. This is confirmed by subsequent cooling simulation. With the intention to improve cooling performance, new cooling channels, adapted to the shape of the moulding insert were constructed in commercial software package. New improved shape of cooling channels is presented in Fig. 4. The inlet and outlet holes are continued in semicircular inlet and outlet channels. Inlet semicircular channel is then divided in four smaller channels which are fitted to injection moulding tool insert surface. The minimum diameter of the channel that could be manufactured by selective laser melting process, is 1 $\mathrm{mm}$, however, the recommended diameter for easy powder removal is $2 \mathrm{~mm}$. The minimum diameter of the constructed cooling channels was about $2 \mathrm{~mm}$.

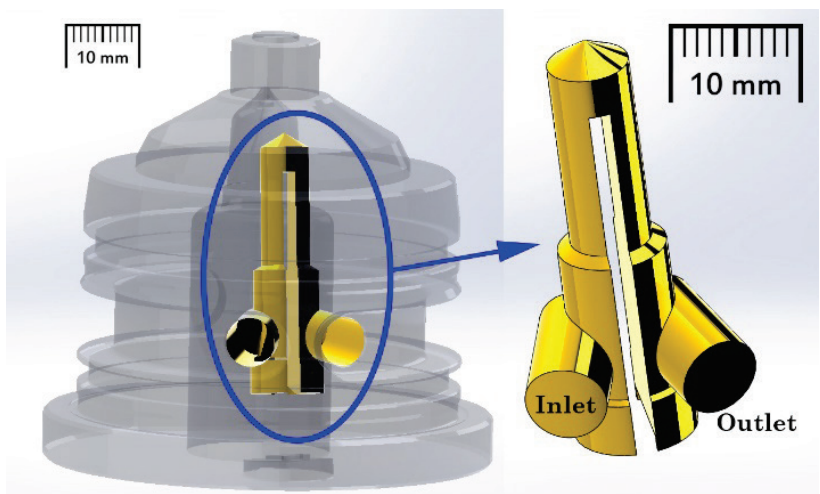

Figure 3 Current (machined) shape of cooling channels in mould tool insert

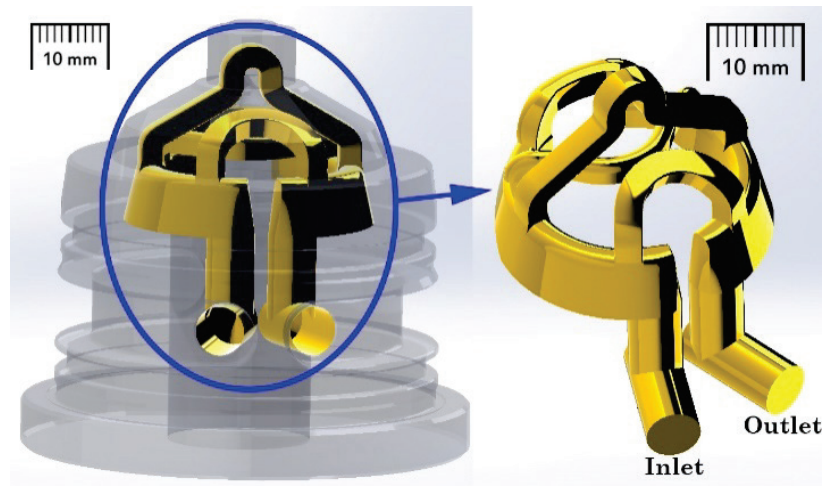

Figure 4 Proposed shape of cooling channels in mould tool insert

\section{Cooling simulation}

Cooling simulation of both current and new improved moulding insert was performed. Unstructured tetrahedral mesh of tool structure and cooling channel was generated in ANSYS ICEM CFD (Release 15.0, 2013). Number of computational cells is presented in Tab. 1. Constant water (cooling fluid) flow rate of $6 \mathrm{l} / \mathrm{min}$ and temperature of 293 $\mathrm{K}$ was prescribed to enter the cooling channel. At the outlet gauge pressure of $0 \mathrm{~Pa}$ (environmental pressure) was defined. $k-\varepsilon$ model was used to model turbulent flow behaviour. The tool is made of steel with density 8030 $\mathrm{kg} / \mathrm{m}^{3}$, specific heat $502,48 \mathrm{~J} / \mathrm{kgK}$ and thermal conductivity $16,27 \mathrm{~W} / \mathrm{mK}$ [8]. Temperature of tool was set to $373 \mathrm{~K}$ in the beginning of simulation. Adiabatic condition was set at the tool outer surface (no heat is lost to the environment). Governing equations describing fluid motion and heat transfer were discretised and solved in ANSYS Fluent (Release 15.0, 2013). 8 s of cooling was simulated with time step size of $0,001 \mathrm{~s}$. Maximum of 40 iterations was allowed within individual step.

Table 1 Number of computational cells

\begin{tabular}{|l|c|c|}
\hline & Old version & New version \\
\hline Tool structure & $359 \mathrm{k}$ & $529 \mathrm{k}$ \\
\hline Cooling channel & $147 \mathrm{k}$ & $232 \mathrm{k}$ \\
\hline
\end{tabular}


Five points were selected on both tool inserts for plotting graph. One on top of inserts and four on an inclined surface at an interval of $90^{\circ}$ as shown in Fig. 5.

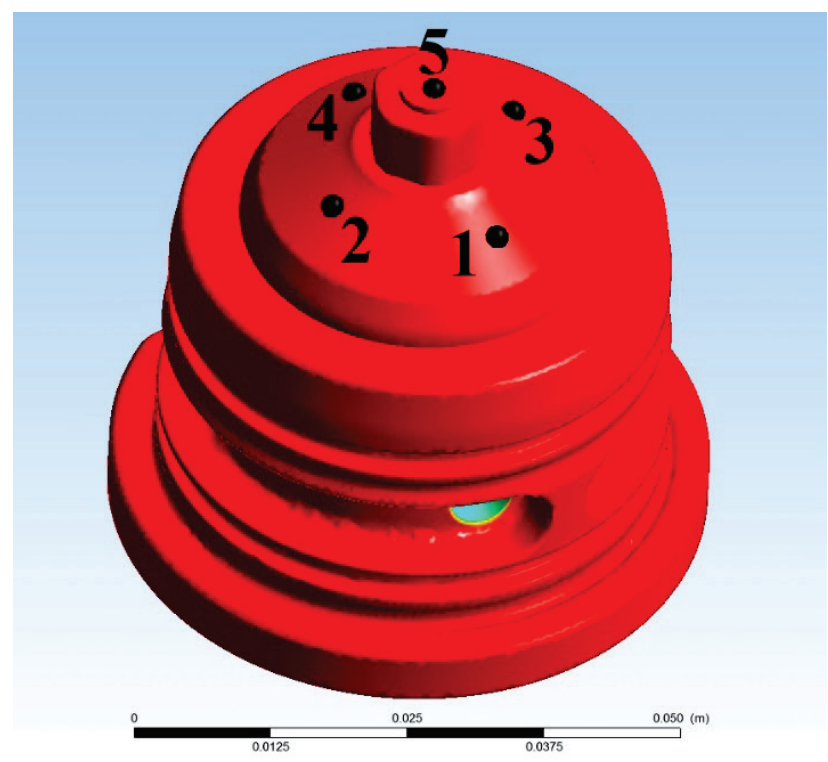

Figure 5 Position of five points on tool insert to capture temperature with the aim to plot a graph and evaluate channels.

In Fig. 6 is presented distribution of temperature on the surface of both tool inserts. Temperature distribution on insert with conventional (machined) cooling channels is presented on the left side of the figure. On the right is conformal cooling insert. Tool insert has temperature of $373 \mathrm{~K}$ on the start of simulation. Then is simulated heat transfer through the body of metal insert when the flow of water with a temperature of $293 \mathrm{~K}$ is established in cooling channels of both tool inserts. The figure represents sequences of temperature distribution during different cooling times. Temperature distribution on the start is shown in the first row, after $2 \mathrm{~s}$ it is in the second row, in the next row the distribution is after $4 \mathrm{~s}$ followed by the distribution after $6 \mathrm{~s}$ and in the end is distribution after $8 \mathrm{~s}$. It is clearly seen that the temperature distribution during cooling of a conventional tool insert is not uniform. Only on the side of the tool, wherein the cooling channels are located (point 1 in Fig. 5) can be observed significant cooling. On other sides of tool insert can be observed negligible cooling down during 8 s. Temperature distribution in the case of proposed conformal cooling channels is extremely different. From the sequences it is observed that cooling down is extremely more uniform and significantly faster. After $8 \mathrm{~s}$ it is seen that the whole upper part of the tool insert reaches temperature of about $293 \mathrm{~K}$ which is the temperature of the inlet water.

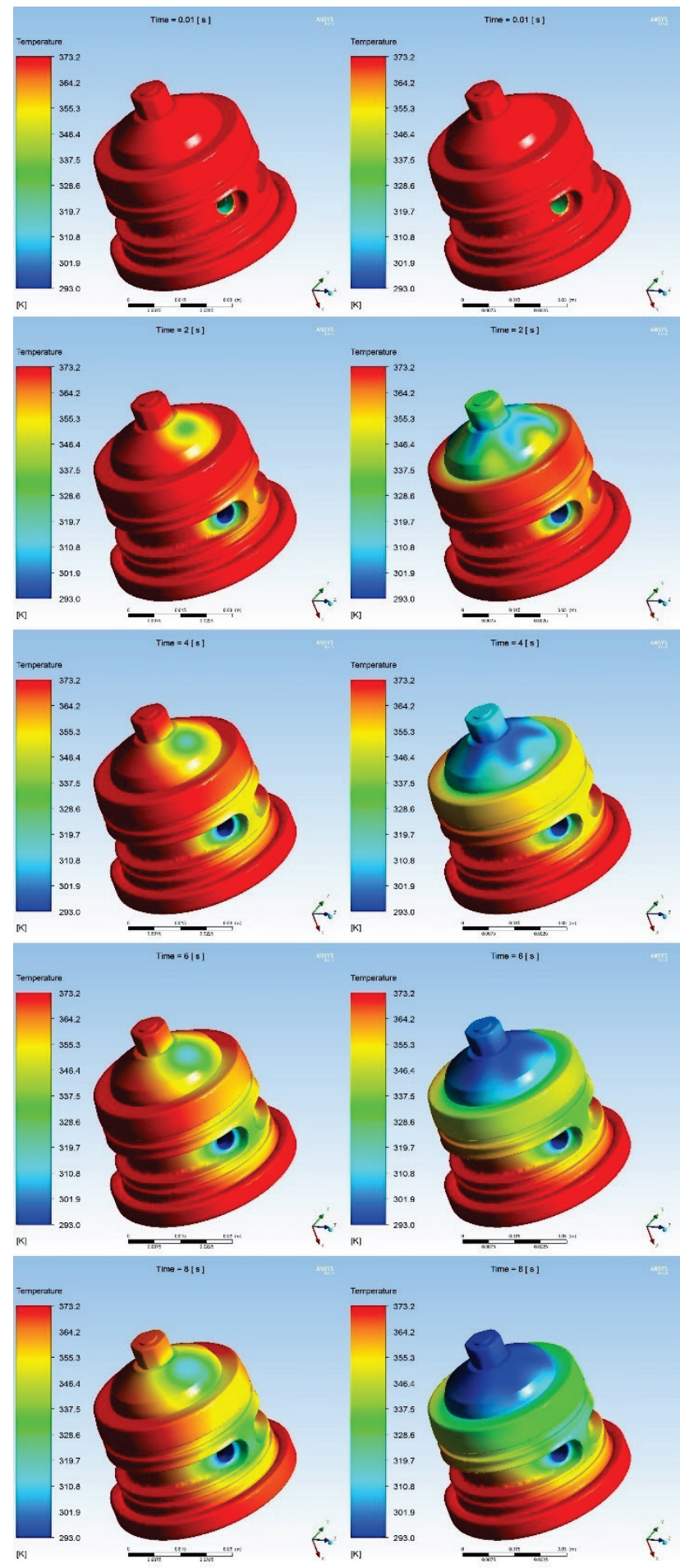

Figure 6 Distribution of temperature on the surface of tool insert during different cooling times. On the left is conventional insert and on the right is conformal cooling insert.

In Fig. 7 is presented a graph which shows that the temperatures in five selected points depend on the time on both tool inserts. It can clearly be seen that there is a rapid decrease of temperature in all five points on tool insert with conformal cooling channels system in the first half of the cooling time. In the second half of the cooling time the temperatures in all five points are very close to the fluid temperature. Here can be seen slight decreasing. On the tool insert with conventional cooling channels only the temperature in point 1 significantly decreases. The final temperature in point 1 does not reach as low temperature as in the case of conformal cooling because 
surrounding material does not allow such rapid cooling. The temperature in other four points decreases very slightly, because there are no cooling channels in the closeness of those four points. The difference between temperatures in point 1 on conventional tool insert and conformal cooling tool insert after $8 \mathrm{~s}$ is $16 \mathrm{~K}$ which represents 5 percent of difference in temperature. Difference in other four points is about 20 percent or about $70 \mathrm{~K}$. Results show that current mould tool insert is really unevenly cooled down because cooling channels are only on one side of the tool insert. There is not enough space on that insert for producing channels on other sides by machining. But with additive manufacturing it is possible to manufacture cooling channels which are evenly arranged on all sides of tool insert.

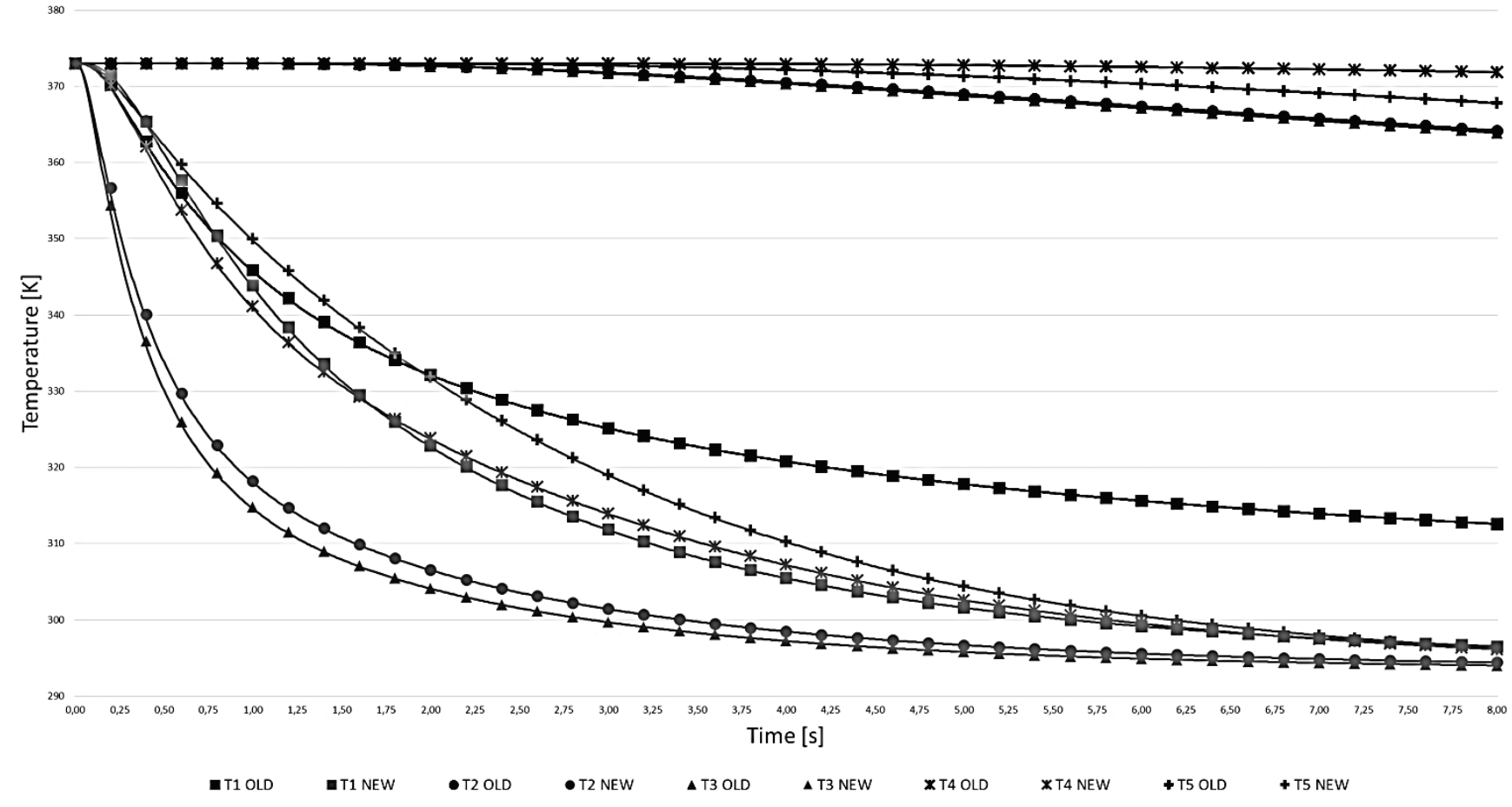

Figure 7 Graph showing temperature in five selected points on both tool inserts as a function of time.

\section{Hybrid manufacturing of conformal cooling injection mould insert}

In this section follows a description of hybrid manufacturing of conformal cooling injection mould insert. Hybrid manufacturing means that one product is divided in two or more parts and then is manufactured with two completely different technologies. In our case one part is done by machining and the other by additive manufacturing of metal powder. Machining makes a product by subtracting material from raw blocks or workpiece. Additive manufacturing technologies are processes opposite to machining. Material is added layer by layer to form the final products. The basis for production with hybrid manufacturing is that some part of product will be produced by technology which is the most advantageous for geometry and for material of this part. Therefore, the base part, this is usually the bottom part of injection mould tool, where the geometry is not complex and where the cooling system has only the straight holes, will be manufactured with conventional CNC machining from a block of raw material. The other part of products where there are curved channels of conformal cooling or another complex geometry will be manufactured by additive manufacturing, as this geometry is not economical or possible to be made by a conventional process.

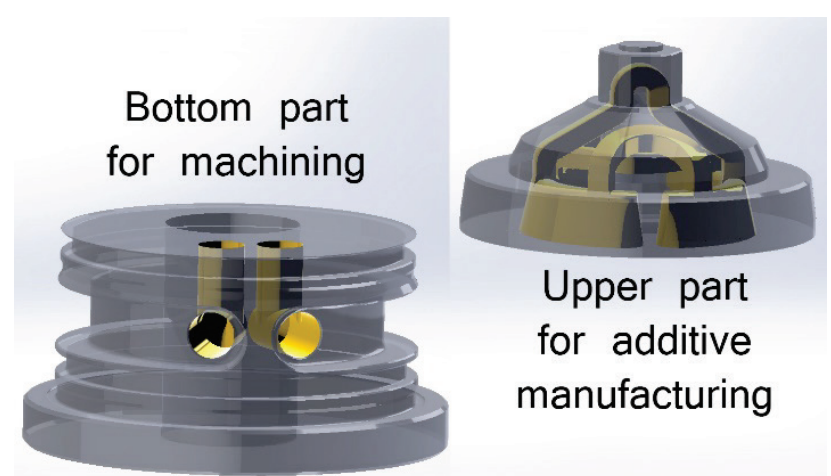

Figure 8 Devided CAD model of conformal tool insert. On the left is the base part for machining and on the right is the upper part for additive manufacturing.

Moulding tool insert was divided in two parts before the start of the manufacturing. These two parts are presented in Fig. 8. To the left is shown base bottom part with relatively simple geometry which is possible to be produced with machining. The upper part of tool insert which is shown on the right side of figure 8 has a very complex geometry because of conformal cooling channels. That part cannot be produced by machining because milling tool cannot reach the inner shape of tool insert.

Afterwards material is chosen. Tool steel MARLOK C1650 is a good choice for tools to be manufactured by 
additive manufacturing [9]. This has among other merits the advantage that it does not harden significantly during the building process. It is highly recommended that the whole product be from the same material, but it is not necessary. In this case both the base and the upper part of the tool insert are made of tool steel MARLOK C1650. With the same material the heat treatment between milling process and additive process is eliminated.

First the base bottom part has been manufactured by machining. The machined base part is presented in Fig. 9. Base part had $0,5 \mathrm{~mm}$ offset in all directions, except in the direction of the $Z$ axis. Offset is demanded because positioning of the base parts on machine for additive manufacturing has some inaccuracy. Offset is demanded also because surface has bad roughness after additive manufacturing; therefore it is necessary that product is finished by machining.

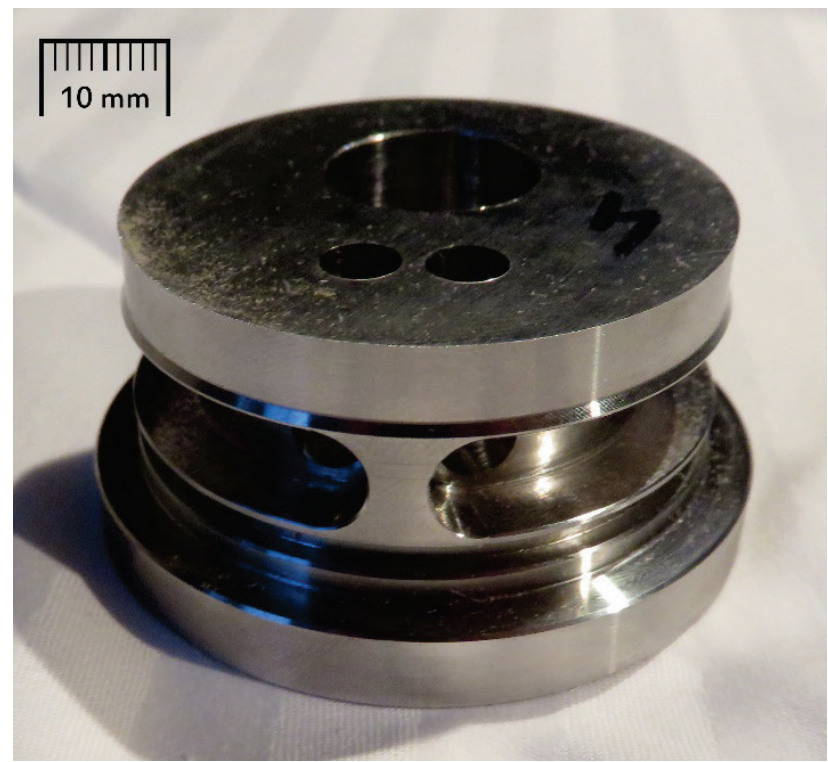

Figure 9 Base machined part of conformal cooling insert.

Then the upper surface of the base part has been sandblasted. With sandblasting more absorptive surface has been provided. Excessive reflectivity does not obtain the required temperature of powder and reflected beams can damage the machine. Five base parts have been manufactured. Afterwards all five base parts have been mounted on pallet, each with two screws. Holes on pallet have known positions and then the position of the tool inserts too. Positions and height of base parts have been forwarded to the control system of additive machine. Pallet with base parts has been clamped on machine for additive manufacturing. Then the empty space between base parts has been filled with powder manually. Powder scraper adds powder on upper surface of base part when the additive process starts. Metal powder in cross section of the first layer has been melted by laser and then the process is going forward layer by layer. After tool insert has been finished on the machine for selective laser melting, loose powder has been removed from channels with air blow and finally finish machining has been performed on tool inserts. Fig. 10 presents tool insert after additive manufacturing and finish machining.

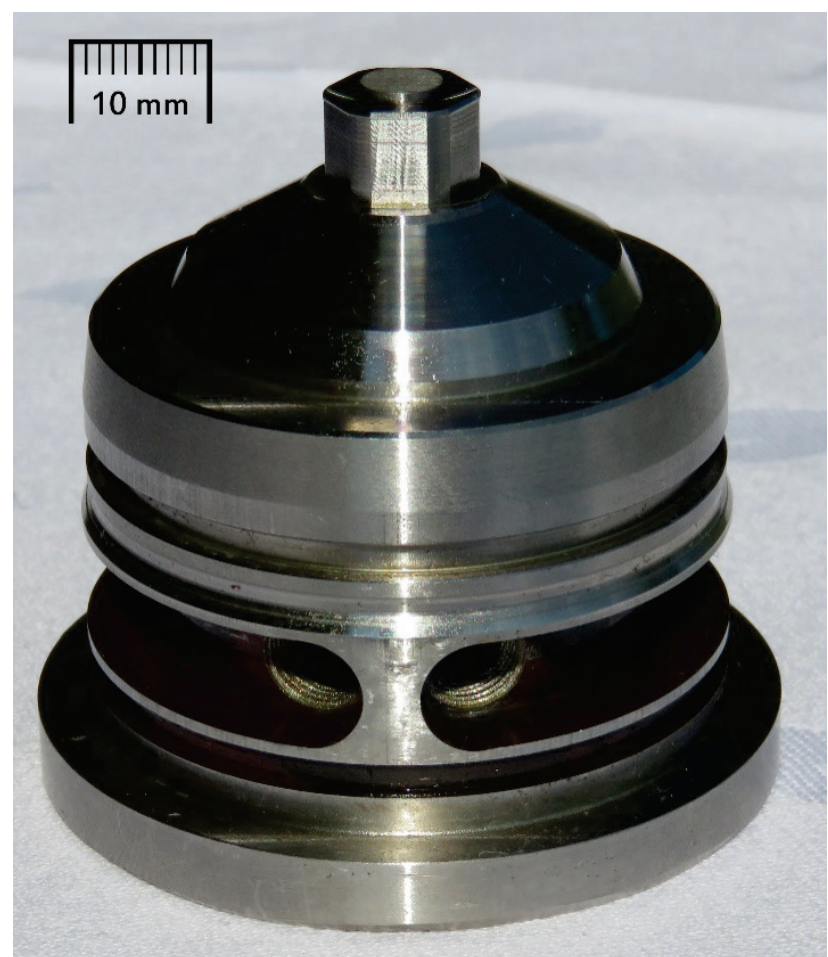

Figure 10 Conformal tool insert after additive manufacturing and finishing machining.
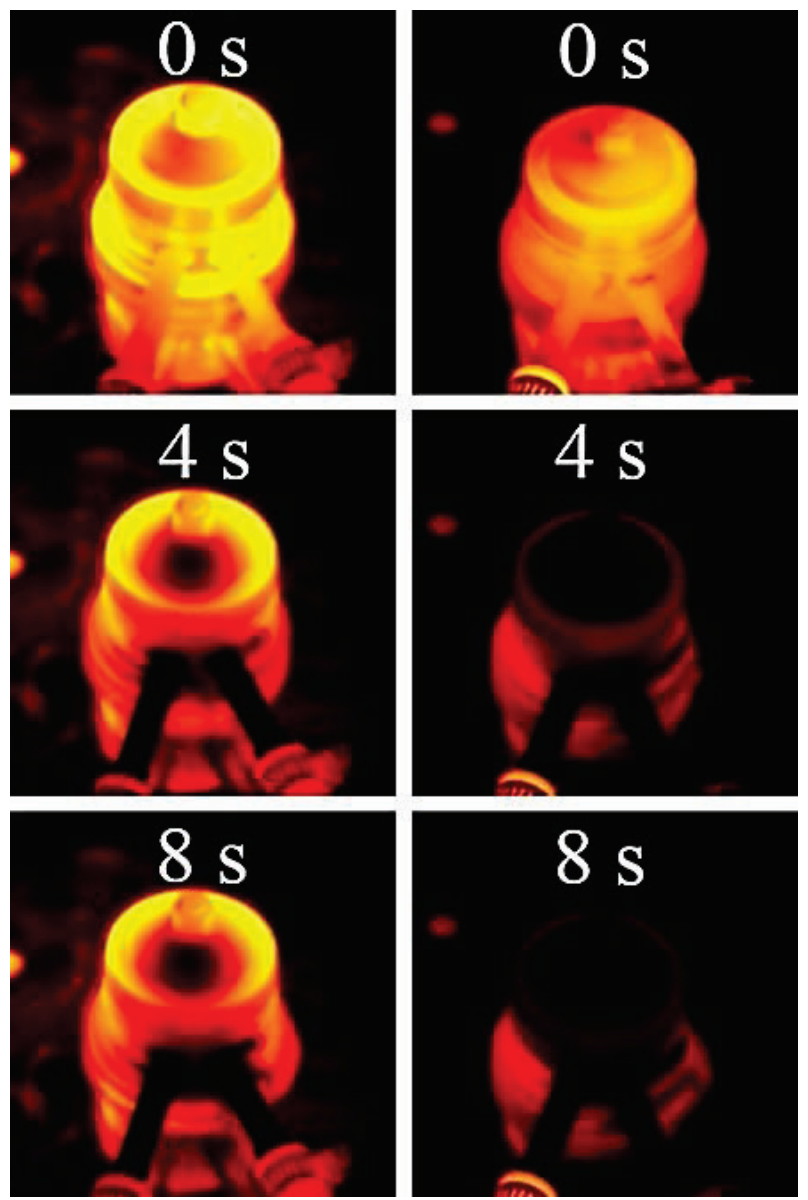

Figure 11 Thermal image of moulding tool insert.

\section{Approving the results of the simulations}

After hybrid manufacturing of the moulding tool insert, recording of the cooling of both moulding tool inserts with a thermal camera was performed to confirm 
the results of the cooling simulation. Fig. 11 presents thermal images of the cooling process of both moulding tool inserts. On the left side, cooling of the conventional tooling insert is presented, whilst cooling of the tooling insert with conformal cooling channels is presented on the right. In the first line thermal images before cooling $(t=0$ s) are shown. The temperature of both tooling insert was about $373 \mathrm{~K}$, due to heating with boiling water. Therefore, the initial temperature in the simulation was set to $373 \mathrm{~K}$. After the tooling inserts were heated to the initial temperature, cooling with water at $293 \mathrm{~K}$ was performed. Thermal images of the tooling insert after $4 \mathrm{~s}$ of cooling are presented in the middle and images after $8 \mathrm{~s}$ of cooling are presented in the bottom of Fig. 11. Very similar results to those in the simulation can be seen. The cooling of the conventional tooling insert was very uneven. Good cooling was detected only around point 1 in Fig. 5. On the other hand, the conformal cooling tooling insert was cooled uniformly over the entire surface.

The conformal cooling tooling was used in a test production series where the cooling cycle was reduced by about $40 \%$.

\section{Conclusions}

The cooling of injection mould inserts was significantly improved with conformal cooling channels. With improved cooling the cooling cycle was reduced by $40 \%$, which is very important in mass production, a good example of which is tube shoulder manufacturing. One even more important aspect is the improvement in the uniformity of the cooling of the studied injection moulding tools. This will improve the quality of injection mould products. Hybrid manufacturing of injection mould tool inserts with conformal cooling channels provides optimal finished products at optimal price. This means that the production cost while using hybrid manufacturing technology is, in our case, reduced by about $20 \%$ with respect to tool inserts made entirely with additive manufacturing. The injection moulding process using tool inserts with conformal cooling channels made by hybrid manufacturing is more economical compared to an injection moulding process using conventional tool inserts made by machining, when taking into consideration the $40 \%$ reduction in the cooling cycle.

Furthermore, the developed injection mould insert with conformal cooling channels will be used in serial production of the tubes shoulders.

\section{References}

[1] Karunakaran, K. P.; Suryakumar, S.; Vishal, P.; Sreenathbabu, A. Low cost integration of additive and subtractive processes for hybrid layered manufacturing. // Robotics and Computer-Integrated Manufacturing. 26, 5(2010), pp. 490-499. https://doi.org/10.1016/j.rcim.2010.03.008

[2] Kerbrat, O.; Mognol, P.; Hascoet, J. Y. A new DFM approach to combine machining and additive manufacturing. // Computers in Industry. 62, 7(2011), pp. 684-692. https://doi.org/10.1016/j.compind.2011. 04.003

[3] Kerbrat, O.; Mognol, P.; Hascoet, J. Y. Manufacturability analysis to combine additive and subtractive processes. //
Rapid Prototyping Journal. 16, 1(2010), pp. 63-72. https://doi.org/10.1108/13552541011011721

[4] Kerbrat, O.; Mognol, P.; Hascoët, J. Y. Manufacturing complexity evaluation at the design stage for both machining and layered manufacturing. // CIRP Journal of Manufacturing Science and Technology. 2, 3(2010), pp. 208-213. https://doi.org/10.1016/j.cirpj.2010.03.007

[5] Yamazaki, T. Development of A Hybrid Multi-tasking Machine Tool: Integration of Additive Manufacturing Technology with CNC Machining. // Procedia CIRP. 42, (2016), pp. 81-86. https://doi.org/10.1016/j.procir.2016.02.193

[6] Grimm, T. User's guide for rapid prototyping, United States of America, Society of manufacturing Engineers, 2004.

[7] Pötsch, G.; Michaeli, W. Injection molding: an introduction, Munich, Carl Hansen Verlag, 2008.

[8] Material Properties Tables. http://www.design1st.com/ Design-Resource-Library/engineering_data/Material PropertiesTables.pdf (08.07.2016)

[9] Company Metso Powdermet Oy: Marlok - Longer die life Better quality, http://www.metsoendress.com/MEP/ info.nsf/WebWID/WTB-051025-22570-FF66/\$File/Marlok $\% 20$ brochure\%202005.pdf (06.05.2015)

\section{Authors' addresses}

David Homar

Faculty of Mechanical Engineering, University of Ljubljana, Askerceva 6, 1000 Ljubljana, Slovenia david.homar@fs.uni-lj.si

\section{Luka Čerče}

Faculty of Mechanical Engineering, University of Ljubljana, Askerceva 6, 1000 Ljubljana, Slovenia luka.cerce@fs.uni-lj.si

prof. dr. Janez Kopač

Faculty of Mechanical Engineering, University of Ljubljana,

Askerceva 6, 1000 Ljubljana, Slovenia janez.kopac@fs.uni-lj.si 